\title{
CALLI INDUCTION OF SOME CHILI PEPPER (Capsicum annuUm L.) GENOTYPES AS MATERIAL FOR GENETIC TRANSFORMATION
}

\author{
Renfiyeni $^{1}$, Yusniwati ${ }^{2}$, Jumsu Trisno ${ }^{3}$ and Jamsari ${ }^{2}$ * \\ ${ }^{1}$ Agricultural Faculty, Mahaputra Muhammad Yamin University Solok, West Sumatera, Indonesia \\ ${ }^{2}$ Plant Breeding Department of Agricultural Faculty, Andalas University, Padang, Indonesia \\ ${ }^{3}$ Plant Pathology Department of Agricultural Faculty, Andalas University, Padang, Indonesia
}

*Corresponding author : ajamsari@yahoo.com

Received : 16 Mei 2015

Accepted : 2 Desember 2015

\begin{abstract}
Calli is one of the materials used for genetic transformation. Studies on calli induction in some pepper genotypes were conducted in the Plant Tissue Culture Laboratory of the Faculty of Agriculture, Andalas University, Padang. This study aimed to obtain calli which can be used as material for genetic transformation. We used three genotypes of chili (Kopay, Kampung and Trisula). Explants were derived from first leaf, cotyledon, epycotyl and hypocotyl obtained from 24 days old chili germination. The study found that all the explants were able to produced calli. From 17 combinations of medium, the two combinations that produced $100 \%$ calli were MS $+\mathrm{BAP}+\mathrm{IAA}+\mathrm{L} 2$ vitamin and MS + 2,4 D. Mediums that can produce organogenic calli were MS $+\mathrm{BAP} 4 \mathrm{mg} / \mathrm{L}$, IAA $0.5 \mathrm{mg} / \mathrm{L}$, L2 vitamin ( Pyridoxin hydroklorit $0.5 \mathrm{~g} / \mathrm{L}$ and Thiamin hydroklorit $0.1 \mathrm{mg} / \mathrm{L}$ ). The colour of calli produced were yellowish green and compact. The study also found that structures develop with a globular phase, followed by a heart shape, torpedo, cotyledonary and eventually form buds. While MS + 2.4 D $4 \mathrm{mg} / \mathrm{L}$ produced yellowish white calli and crumb, it could not grow organogenic calli.
\end{abstract}

Keywords: crop-livestock integration, palm oil by-products technology.

\section{INTRODUCTION}

Chili pepper (Capsicum annuum L.) is one of the most important horticulture crops, because it has a high nutritional and economic value. Chili peppers are rich in vitamins $\mathrm{A}$ and $\mathrm{C}$ that are used to mix food and medicine. Chili contains a number of chemicals including volatile oils, fats, capsaicinoid, carotenoids, vitamins, protein, fiber and mineral elements (Bosland and Votava, 2000). Along with the increase in population the demand for red chili is also increasing. National chili production in 2009 was $1,378,727$ tonnes from a harvested area of 233,904 ha and average productivity of 5.89 tonnes / ha (The Central Bureau of Statitik, 2011). Potential outcomes of local chili can reach 12-20 tonnes / ha and the yield potential of red chili hibdrida can reach 36 tons / ha (Prajnanta, 2007). When compared with the red chili yield of other Asian countries, Indonesia lags far. For example, Chinese red pepper yield reached 14.5 tonnes / ha (Rubatzky and Yamaguchi, 1997 cit Yusniwati, 2008). One of the many diseases that attack chili peppers is Pepper Yellow LeafCurl Virus (Pep YLCV) caused by a Gemini virus. This virus is dangerous because it can decrease the production of chili. Symptoms of the virus on infected plants include yellow spots on the leaves that eventually makes the plant turn curly, so the flowers cannot develop into fruit.

Some control efforts have been made, including improving ways of farming, the use of natural enemies, field sanitation or the use of pesticides, but this disease has not been able to be controlled. Currently attempts focus on improving plants resistance. The use of resistant plants is one way which was considered effective and efficient (Nono-Wondim et al, 1991). Until now chili varieties that are resistant to yellow curl virus disease have not been found so there is not a source of resistance genes. (Sulandari, 2004). 
Attempts to produce resistant plants cannot be separated from the activities of plant regeneration in vitro. First plants must be regenerated in vitro to do the assembly plant resistance through genetic transformation. Red pepper plant is a plant that is difficult to genetically engineer. This is evident from the low number of publications about genetically modified red peppers in a scientific journal. This is caused by the difficulty of regenerating red pepper shoots in vitro and regenerating explant inoculation results in agrobacterium. Both of these complicate the process of genetic engineering on red pepper (Yusniwati, 2008). Attempts to obtain transgenic pepper have been hampered by the difficulty of regenerating transformed explants (Ahmad et al, 1997), however non-transgenic plant regeneration in red pepper has been reported (Gunay and Rao, 1978; Valera-Montero and Ochoa-Alejo, 1992 cit Ahmad et al, 2002).

Tissue culture is a method to isolate the parts of the plant such as protoplasm, cell, group of cells, tissues and organs, and grow them in aseptic conditions, so that the parts can multiply and regenerate into complete plants (Gunawan, 1988). The success of plant propagation by tissue culture methods are influenced by many factors, such as genetic traits of plants, selection of plant parts used as explant source, age of explants, the composition of the growth media, plant growth regulators and culture environment (George and Sherington, 1984). According to Gubis et al (2003), there are three factors that most influence the success of in vitro plant regeneration; genotype, explant type and media composition.

In almost all plants, parts of the young in which the cells are actively dividing are the best parts for explants (Wattimena, 1991). When explants are taken from older plant organs the process of cell division and regeneration tends to decrease. Therefore it is advisable to use young tissue and soft tissues are generally easier to proliferate than woody tissues or older tissues.

Regeneration in vitro of pepper plants can be done via protoplast, hypocotyl, cotyledon, young leaves, direct somatic embryogenesis and shoot regeneration from seeds at different chili cultivar (Christopher and Rajam, 1996; Gunay and Rao, 1978; Diaz et al., 1988). These regeneration procedures need to be modified for different varieties of chili. The variety of chili has an influence in the regeneration of different explants and this makes the need for propagation protocol optimization that are specific to each cultivar (Ochoa Alejo and Ireta-Moreno, 1990). Differentiation of low frequency, difficulty of shoot elongation and low repetition ability is the main obstacle in the development of gene engineering chili (Da bauza and Pena, 2001).

From experiments by Ashrafuzaman et al (2009) on pepper plants with hypocotyl and cotyledon explants on MS medium supplemented with BAP combined with NAA, IAA or AgNO3. Among the combinations of hormones, callus produced by hypocotyl most (95\%) with the addition of $5 \mathrm{mg} / \mathrm{LBAP}$, $0.1 \mathrm{mg} / \mathrm{L} \mathrm{NAA}$, followed by cotyledons (80\%) with $5 \mathrm{mg} / \mathrm{L} \mathrm{BAP}, 1 \mathrm{mg} / \mathrm{L}$ IAA. While the initiation of the fastest callus obtained in cotyledons and hypocotyl with MS medium plus $5 \mathrm{mg} / \mathrm{LBAP}$ and $3 \mathrm{mg} / \mathrm{L}$ AgNO3.

One of the difficulties in plant tissue culture techniques is to determine the optimum nutritional requirements for the growth of explants. This condition is very different for each species of plant so it not possible to recommend one type of media for various species and parts of plants as explants (Taji et al, 1992).

Faced with the difficulty of regeneration of red peppers, this research is conducted on the use of plant growth regulators auxin and cytokinin for multiple genotypes which enables chili pepper plants to produce callus that is organogenic. The callus produced will be used as material for genetic transformation.

\section{MATERIALS AND METHODS}

The experiment was conducted at the Tissue Culture Laboratory, Faculty of Agriculture, University of Andalas. The material used in this study is the seed chili (Kopay, kampung and Trisula), MS medium (Murashige and Skoog), plant growth regulators (BAP, IAA, 2,4 D), sucrose, agar, etc. Tools used included a culture bottle, magnifying glass, microscope, scalpel, $\mathrm{pH}$ meter, measuring cup, 
glass cup, laminar air flow cabinet, sprayer, digital cameras, analytical balance, autoclave, petridish, scissors, etc.

\section{Seed germination in vitro}

Seeds of chili Kopay, kampung and Besar germinated in vitro and eksplants were taken from the following parts; first leaf, hypocotyl, cotyledon, and epycotyl. Transformations used callus that was already growing well and able to regenerate. Explants were derived from 20-day-old seedlings after planting. Before planting, the chili seeds were surface stratified sterilized using Sodium Hypochlorite $20 \%$ ( 3 times each for $10 \mathrm{~min}$ ) and rinsed with sterile distilled water 3 times. Furthermore, the seeds were soaked with sterile distilled water for 24 hours. Seeds were germinated on MS medium without growth regulators, with $3 \%$ sucrose and $0.8 \%$ plant agar.

\section{Calli induction}

Chilli Seeds were germinated until the age of 24 days. Seeds were removed from the bottle and the first leaf explants, cotyledon, epycotyl and hypokotil were taken. Calli induction used MS basic medium with 17 combination contained plant growth regulators ( BAP, IAA, NAA, IBA, 2,4 D, Kinetin, TDZ), L2 vitamins (Thiamin hidroklorit and Pyridoksin hidroklorit) (Table. 1). Each added Sucrose 30 $\mathrm{g} / \mathrm{L}$, plant agar $8 \mathrm{~g} / \mathrm{L}$, at $\mathrm{pH}$ 5.8. Explants were cultured for 2 weeks at a temperature of $22^{\circ} \mathrm{C}$ to form calli.

Table 1. Combination of medium used for calli induction

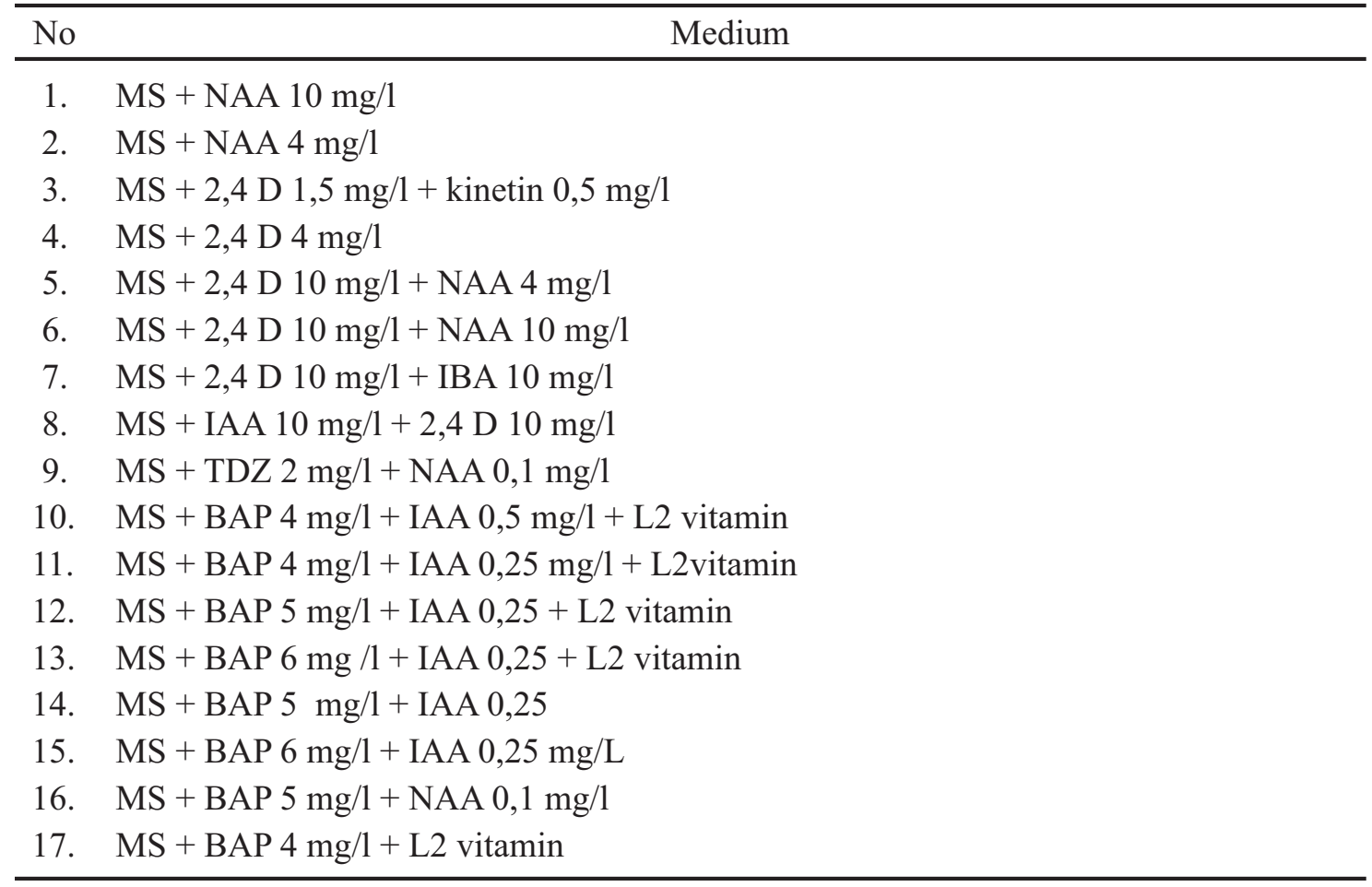

\section{RESULTS AND DISCUSSION}

Of the 17 combinations of media used two combinations produced $100 \%$ calli, MS $+2.4 \mathrm{D} 4 \mathrm{mg} / 1 \mathrm{BAP}$ and MS $+4 \mathrm{mg} / 1+$ IAA $0.5 \mathrm{mg} / 1+$ vitamin L2. These two media combinations induced calli on all three genotypes chilli used. Other combinations produce calli less than $100 \%$. The effect of explant sources used can be seen in Table 2. 
Table 2. Influence of explant source to calli growth while on MS + L2 Vitamin + BAP + IAA and $\mathrm{MS}+2,4 \mathrm{D}$

\begin{tabular}{llccc}
\hline \multirow{2}{*}{ No } & \multirow{2}{*}{ Eksplant } & \multicolumn{3}{c}{ Calli growth while (days) } \\
\cline { 3 - 5 } & & MS medium + L2 Vitamin $+B A P+$ IAA & Kopay & Trisula \\
\hline & & 4 & 4 & 5 \\
\hline 1. & First leaf & 6 & 6 & 6 \\
2. & Cotyledon & 6 & 6 & 6 \\
3. & Hipocotyl & 4 & 4 & 5 \\
\hline 4. & Epicotyl & & & \\
\hline & & 3 & 3 & 4 \\
\hline 1. & First leaf & 4 & 3 & 4 \\
2. & Cotyledon & 4 & 3 & 4 \\
3. & Hipocotyl & 3 & 3 & 4 \\
4. & Epicotyl & MS medium + 2,4 D & \\
\hline
\end{tabular}

Explants used in this study consisted of the first leaf, cotyledon, hypocotyl and epycotyl. Each explant had the ability to produce calli, but at different times. MS + 2,4 D $4 \mathrm{mg} / 1$ medium more quickly produced calli than MS + BAP $4 \mathrm{mg} / 1+$ IAA $0.5 \mathrm{mg} / 1+\mathrm{L} 2$ vitamin on four sources of explants used. The first leaf and epycotyl produced faster than cotyledon and hypocotyl induced calli. Young tissue produced calli more easily. Young tissue has cells that actively divide and differentiate. Old tissue have cells with a reduced activity of division and differentiation (Watimena, 1991).

Two types of calli were generated; 1 . calli with a yellowish white color and crumb produced by media $\mathrm{MS}+2,4 \mathrm{D} 4 \mathrm{mg} / 1,2$. Calli with a yellowish green color and a compact produced by the media MS + BAP $4 \mathrm{mg} / 1+$ IAA $0.5 \mathrm{mg} / 1+\mathrm{L} 2$ vitamin.

Calli generated by media containing 2,4-D is generally quicker to form and grow, hence the larger size. Medium containing 2,4-D form a calli at the age of 3 days, while medium containing BAP formed calli four days after planting. After further observation, it became apparent that the yellowish green and compact calli is organogenic calli, while the yellowish-white and crumb is non-organogenic calli. This means MS + BAP $4 \mathrm{mg} / 1+\mathrm{IAA} 0.25 \mathrm{mg} / 1+\mathrm{L} 2$ vitamin produced organogenik calli, while MS + 2.4 D, produced non organogenic calli.

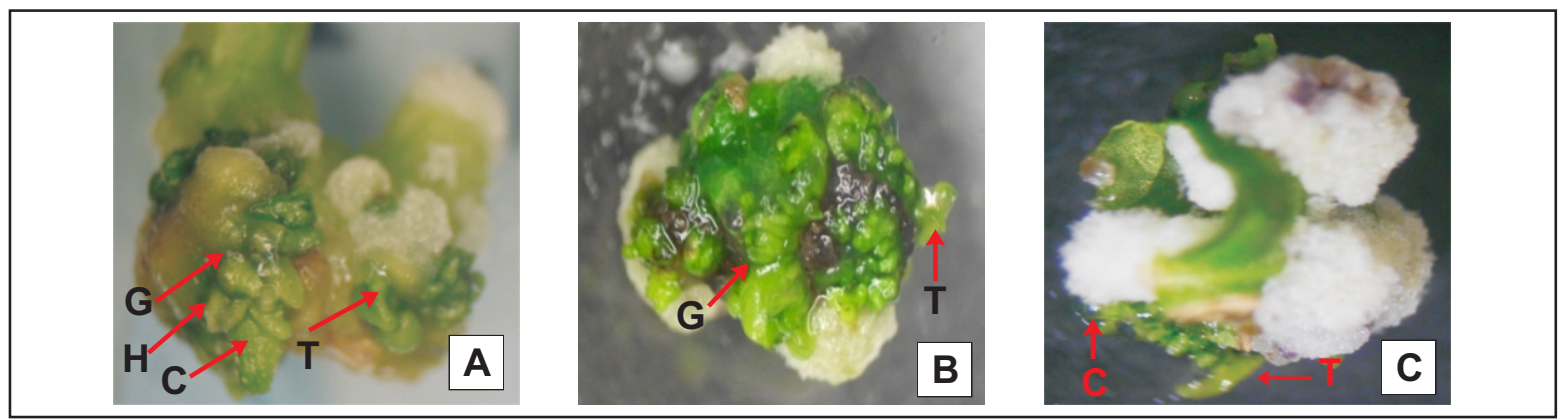

Figure 1. Growth of callus (organogenik) of 3 genotype chili on the medium MS + BAP $4 \mathrm{mg} / 1+$ IAA $0.25 \mathrm{mg} / 1+\mathrm{L} 2$ vitamin 2 weeks after induction of A. Kopay, B. Trisula C. Kampung $(\mathrm{G}=$ Globular stage, stage $\mathrm{H}=$ Heart shape, $\mathrm{T}=$ Torpedo stage, $\mathrm{C}=($ Cotiledonary stage $)$

From these observations it can be seen that the calli grown on MS medium $+\mathrm{L} 2+$ Vitamin BAP and IAA will produce shoots, because it showed more calli development phase, as has been the formation of globular phase, torpedo and cotyledonary as shown in Figure 1. While calli grown on MS + 
$2.4 \mathrm{D}$ did not show the growth phase of globular, heart, torpedo and cotyledonary, so it can not differentiate to form shoots (Figure 2). Thus the resulting calli is not organogenic. It can be concluded that not all calli generated from all media can produce organogenic calli. Organogenik calli will experience a developmental phase to form buds. The development begins with a globular-shaped calli phase, then the heart, torpedo, cotyledonary and finally forming buds. This development is highly related to the composition of growth regulators available in the media, in this case the interplay between auxin and cytokinin. As stated by Katuuk (1989), Akyas (1990), Bhaskaran and Smith (1990), the essence of organ differentiation in explants regulated by each influences the other work between auxin and cytokinin. If cytokines are relatively high concentrations of auxin will encourage bud formation. Conversely if the auxin is relatively higher than cytokines, this will lead to the formation of roots. This situation does not take place by itself, because there is still the need for additional external growth regulators of the concentration, among others, depending on the concentration of endogenous hormones that existed at explant.

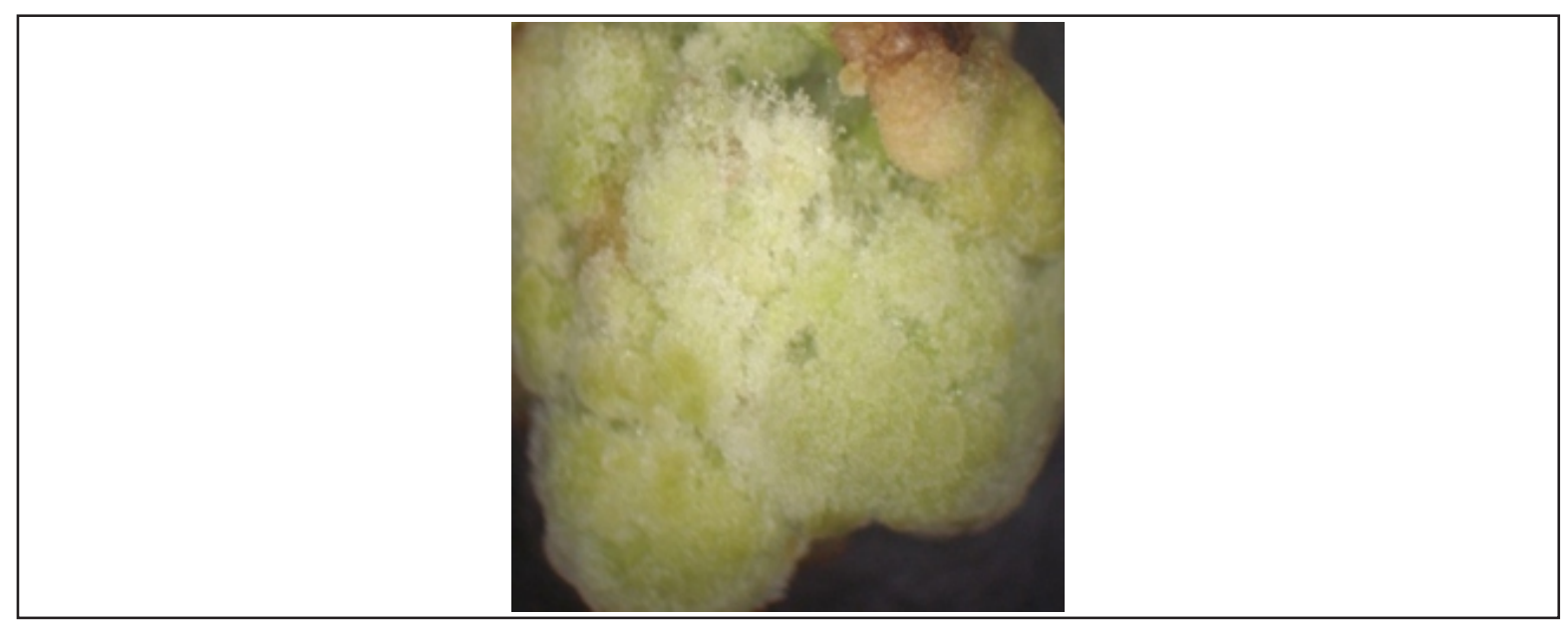

Figure 2. Growth of callus (non organogenic) on the medium MS +2,4-D, 2 weeks after the induction there is no structure of globular, heart, torpedo and kotiledonary.

\section{CONCLUSION}

From this research it can be concluded that the medium MS + L2 Vitamin (Pyridoxin hidroklorit $0.5 \mathrm{mg} / \mathrm{L}$ and Thiamin hidroklorit $0.1 \mathrm{mg} / \mathrm{L})+\mathrm{BAP} 4 \mathrm{mg} / \mathrm{L}+\mathrm{IAA} 0.5 \mathrm{mg} / 1$ can produce organogenic calli for all three genotypes chili (Kopay, Kampung and Trisula). Explants derived from the first leaf, epycotyl, hypocotyl and cotyledons. While the media MS + 2,4 D can not produce organogenic calli for three genotypes chili. Organogenic calli is yellowish green and compact structure, whereas non organogenic calli is yellowish white and crumb structure (containing a lot of water).

\section{ACKNOWLEDGEMENTS}

Many thanks were addressed to the Director General of Higher Education, Ministry of National Education of Indonesia for funding this research through scheme of the National Strategic Grants for fiscal year 2011-2012.

\section{REFERENCES}

Ahmad, I.B., M.N. Hanina, A.M. Mahir, and A. Zaiton, 2002. Transformation of Red Chilli Variety Cilibangi-2 (Capsicum annum L.) with cDNA of Cucumber Mosaic Virus Coat Protein Gene by Direct Uptake. Pakistan Journal of Biological Science 5 (6): 683-687. 
Ahmad,I.B.,Y.H.Leong and Y.S.Lee, 1997. Analysis of factors affecting transformation of Capsicum annuum with Agrobacterium. Proceedings of 9th National Biotechnology Seminar: Positioning National R \& D in Biotechnology for Global Competitiveness, pp: 131-133.Penang Malaysia 2326 November 1997

Ashrafuzzaman, M., M.M.Hosain, M.Razi Ismail, M.Shahidul Haque, S.M.Shahidullah, and ShaninUz-Zaman, 2009. Regeneration potential of seedling expalnts of chili (Capsicum annuum). African Journal of Biotechnology Vol 8(4), pp 591-596. Feb 2009

Aykas , A.M. 1990. Expectations and limitations of using growth regulators in the engineering of crop cultivation in the collection of conference papers National Agrochemicals, January 20, 1990. Jatinangor . It 9-17.

Bhaskaran, S and R.H. Smith, 1990. Cell biology and molacular genetic regeneration in 1 Courncereal tissue culture, Journal Crop Science $30: 1328-1336$

Bosland,P.W. and Votava, E.J. 2000. Peppers : Vegetables and spice capsicums. Crop Production science in Horticulture 12. CAB Internasional Publishing Wallingford, England, U.K p:204

Christopher, T and Rajam M.Y, 1996. Effect of genotype, explants and medium on in vitro regeneration of red pepper. Plant Cell Tissue Organ Cult. 46: 245-250

Dabauza, M., Penal L. 2001. High efficiency organogenesis in sweet pepper (Capsicum annuum L.) tissue from different seedling explants. Plant Growth Regul. 33. 21-229

Diaz I, Moreno R., Power J.B, 1988. Plant regeneration from protoplasts of Capsicum annuum. Plant Cell Rep. 7:210-212.

George, E.F and P.D. sherington, 1984. Plant Propagation by Tissue Culture. Handbook and Directory of Comercial Laboratory. Exegheties Ltd. England. 709p

Gunawan, L.W. 1988. Plant Tissue Culture Technique . PAU Biotechnology.IPB. Bogor

Gunay, S. And Rao P.S, 1978. In vitro plant regeneration from hypocotyls and cotyleldon explants of red pepper (C. annuum) Plant Sci. Lett. $11: 365-372$

Katuuk , J.R.P. 1989. Tissue Culture Technique in plant micropropagation . Ministry of Education and Culture . Directorate General of Higher Education . Educational Institutions Development Project Personnel . Jakarta . 188 p.

Nono-Wondim, R., G. Marchoux, E. Pochard, A. Palloix, and K. Gebre Selassie. 1991. Resistance of pepper lines to movement of Cucumber Mosaic Virus. J. Phytopathol. 137 : 21-32

Prajnanta, F. 1999. Planting Ways Chili in rainy season. Penebar Swadaya. Jakarta.

Sulandari, S. 2004. Characterization biology, serology and DNA fingerprinting analysis of viruses that cause disease yellow leaf curly chili . Dissertation Graduate School of IPB Bogor

Taji, M. Acram, Dood, A., William and Willians R.Ricard. 1992. Plant tsissue culture practise. Botani Departemen and Departemen of Agronomi and Soil Science, University of New England, Armidale. Centre for Biological Population Management Queeslend University, Brisbane.

The Central Bureau of Statitik . 2011. Harvested Area , Production and Productivity Chili , 2009. www.bps.go.id (09 March 2011).

Yusniwati, 2008. Drought Tolerant Transgenic Chili strains with P5CS Gene Encoding Key Enzyme Biosistesis Proline: Regeneration and Characterization regenerants. Dissertation Graduate School of Bogor Agricultural University. $119 \mathrm{p}$

Watimena, G.A. 1991. Plant Biotechnology . Plant Tissue Culture Laboratory team . University Centre of Biotechnology.IPB. Bogor 